\title{
Effectiveness of afatinib after ineffectiveness of gefitinib in an advanced lung adenocarcinoma patient with a single EGFR exon 20 S768I mutation: a case report
}

This article was published in the following Dove Press journal: OncoTargets and Therapy

\author{
Hua Duan' \\ Yanmei Peng' \\ Huijuan Cui \\ Yuqin Qiu' \\ Qiang $\mathrm{Li}^{\prime}$ \\ Jingyi Zhang' \\ Wen Shen' \\ Chenyao Sun' \\ Chufan Luo' \\ 'Department of China-Japan \\ Friendship Hospital, Beijing University \\ of Chinese Medicine, Beijing, China; \\ ${ }^{2}$ Department of Oncology, China- \\ Japan Friendship Hospital, Chaoyang, \\ Beijing, China
}

\begin{abstract}
Epidermal growth factor receptor-tyrosine kinase inhibitors have improved progression-free survival and overall survival in non-small-cell lung cancer (NSCLC) patients with sensitive mutations. However, response of uncommon mutation to epidermal growth factor receptor-tyrosine kinase inhibitors is still unclear. S768I is one of the uncommon mutations. A female patient with advanced NSCLC with a single S768I mutation achieved effectiveness from afatinib after showing no response to gefitinib. The patient had progression-free survival after taking afatinib for 6 months, and her follow-up is continuing. It suggests that afatinib may be a more effective treatment for NSCLC patients with a single S768I mutation, compared to first-generation tyrosine kinase inhibitors.
\end{abstract}

Keywords: NSCLC, epidermal growth factor receptor-tyrosine kinase inhibitors (EGFR-TKIs), S768I, afatinib, gefitinib

\section{Introduction}

Lung cancer is the leading cause of cancer deaths according to GLOBOCAN estimates and has caused stressful burden on the society. ${ }^{1}$ Cancer Statistics in China revealed similar phenomenon. ${ }^{2}$ In recent years, epidermal growth factor receptor-tyrosine kinase inhibitors (EGFR-TKIs) have improved the progression-free survival (PFS) in non-small-cell lung cancer (NSCLC) patients with sensitive mutations, compared to traditional chemotherapy ${ }^{3-5}$ (9.2-13.1 vs 4.6-6.3 months). The sensitive mutations include deletions in exon 19 or L858R mutations in exon 21, which account for $85 \%$ of all epidermal growth factor receptor (EGFR) mutations and are associated with sensitivity to EGFR-TKIs. ${ }^{6,7}$ Different generations of EGFR-TKIs showed no significant differences in sensitive mutations. Meanwhile, the incidence rates of uncommon mutation such as G719X, S768I, L861Q, and exon 20 insertion mutations are 4\%-13\%, and their response effects to EGFR-TKIs remain unclear. ${ }^{8-10}$

Exon 20 p.S768I mutation is one of the uncommon mutations. Previous reports contradict on which generation has a better effect on S768I mutation. ${ }^{8-10}$ LUX-Lung 2, LUX-Lung 3, and LUX-Lung 6 studies ${ }^{11}$ showed that afatinib (Boehringer Ingelheim Pharmaceutical Co., Ingelheim, Germany) revealed benefits among eight patients who carried S768I mutation. However, only one case had the single S768I mutation. Here, we report a case of afatinib's response in an advanced NSCLC female patient who failed treatment with gefitinib (AstraZeneca plc, London, UK).
Correspondence: Huijuan Cui Department of Oncology, China-Japan Friendship Hospital, No 2, Yinghua Dong Jie, Chaoyang District, Beijing 100029, China

Tel +86 I39 II 835018

Email cuihj1963@sina.com 


\section{Case report}

In March 2013, a 52-year-old Chinese female with no smoking history had sudden coughs with bloody sputum and chest pain. Positron emission tomography-computed tomography (CT) taken in Peking Union Medical College Hospital showed a mass in the left upper lung sized $39 \times 49 \mathrm{~mm}^{2}$ and the standard uptake value was 5.8. Meanwhile, several masses sized $8 \mathrm{~mm}$ in the mediastinum were observed without increased radioactive uptake. On April 16, 2013, upper left lung resection and mediastinal lymph node dissection were performed. Finally, the patient was diagnosed with lung adenocarcinoma on the left upper lobe with stage IIa (pT2aN1M0), as shown in Figure 1. Molecular pathology suggested EGFR exon 20 p.S768I mutation $(2303 \mathrm{G}>\mathrm{T}$ ). Also, in her family, her father and one uncle died of lung cancer and another uncle died of kidney cancer.

From June to October 9, 2013, the patient was treated with adjuvant chemotherapy in another hospital (pemetrexed plus cisplatin, but the dose was unknown) for four therapy circles. Chest CT scan showed no recurrence. However, on October 10, 2014, a regular chest CT scan showed a new mass with a diameter of $10 \mathrm{~mm}$ in the left upper lung and several new masses in the right lung with a maximum diameter of $4 \mathrm{~mm}$, that is, metastasis in mediastinal 4R, 4L, six regions, and left pleural effusion.

From October 2014 to December 2016, the patient accepted four-line therapies with chemotherapies and bevacizumab. Among the treatments, the fourth line treatment maintained 15 cycles and the patient benefited the longest PFS lasting for 14 months (Table 1). On December 30, 2016, a circulating tumor DNA liquid biopsy by the Amplification Refractory Mutation System was performed. And the result was the same as the surgical specimen two years ago (Figure 2). Because afatinib was not available in China at that time, we recommended the first-generation EGFR-TKI

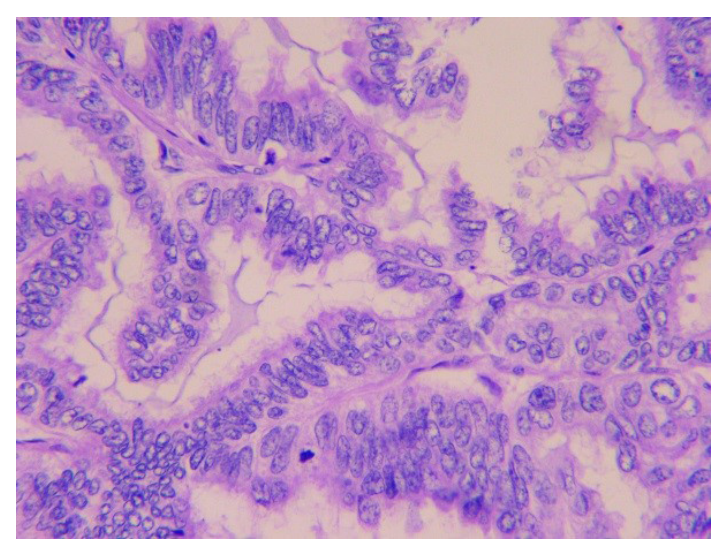

Figure I High-power magnification of a tumor specimen shows adenocarcinoma (400x). gefitinib ( $250 \mathrm{mg} /$ day) with bevacizumab. One month later, the chest CT scan revealed that the metastases increased widely in both lungs, indicating that gefitinib was of primary resistance (Figure 3A and B). On March 3, 2017, the patient started taking afatinib ( $40 \mathrm{mg} /$ day) with bevacizumab. The chest CT scan revealed the metastases shrank obviously after 1 month (Figure 3C). After 3 months, the patient had two-grade diarrhea and one-grade rash on the back neck. The efficacy evaluation was partial response. Now, the patient has PFS for 6 month (Table 1).

The patient has signed written informed consent for publishing the case details and any accompanying images.

\section{Discussion}

The patient was diagnosed with left lung adenocarcinoma without sensitive EGFR mutation. The initial stage was IIa, and the margin was negative. According to the National Comprehensive Cancer Network (NCCN) Guideline, ${ }^{12}$ chemotherapy was recommended as the adjuvant therapy. After four cycles of therapy and 16-month disease-free survival, locoregional recurrence and distant metastases occurred. Chemotherapy or bevacizumab combined with chemotherapy was recommended according to the NCCN Guideline. ${ }^{12}$

According to the NCCN Guideline, bevacizumab, a humanized monoclonal antibody against vascular endothelial growth factor, can be used as the first-line therapy for lung adenocarcinoma until the disease progressed. ${ }^{12}$ Many classic clinical studies ${ }^{13-16}$ also proved its efficacy in NSCLC, compared with traditional chemotherapy. The classic ECOG4599 ${ }^{16}$ and BEYOND ${ }^{13}$ studies have proved that bevacizumab with carboplatin/paclitaxel was well tolerated and resulted in a clinically meaningful treatment benefit in Chinese patients with advanced nonsquamous NSCLC. Table 1 shows the survival benefits from chemotherapy or bevacizumab.

When the disease progressed, the tissue samples could not be obtained due to the poor physical strength of the patient, so we performed circulating tumor DNA liquid biopsy, which was the feasible sample for EGFR mutation analysis. ${ }^{17,18}$ EGFR exon 20 S768I mutation was detected just like before. Hellmann et a $\mathrm{l}^{19}$ reported a case whose mass spectrometry genotyping revealed EGFR S768I mutation among surgical specimens in 2001, 2003, and 2013, respectively. Besides, erlotinib had resulted in partial radiographic response until T790M mutation occurred.

To the best of our knowledge, this is the first case wherein a patient with S768I mutation received first- and secondgeneration EGFR-TKIs successively, and the response was completely different. The S768I mutation is a rare subset of 
Table I Detailed medications and treatment

\begin{tabular}{|c|c|c|c|c|c|}
\hline Time periods & Treatment & Line & Cycle & RECIST & PFS (month) \\
\hline From November 2014 to January 2015 & $\begin{array}{l}\text { Fosfamide } 2 \mathrm{~g} \text { days } \mathrm{I}-3 \text { and pemetrexed } 800 \mathrm{mg} \\
\text { day } 4 \text {, every } 2 \mathrm{I} \text { days }\end{array}$ & 1 & 2 & PD & - \\
\hline From March 17 to April 18, 2015 & $\begin{array}{l}\text { Navelbine } 40 \mathrm{mg} \text { day } \mathrm{I} / \text { day } 8 \text { and carboplatin } 400 \mathrm{mg} \\
\text { day } 2 \text { and bevacizumab } 400 \mathrm{mg} \text { day I, every } 2 \mathrm{I} \text { days }\end{array}$ & 2 & 6 & PR & 4 \\
\hline From May 12 to July 29,2015 & $\begin{array}{l}\text { Navelbine } 40 \mathrm{mg} \text { day I/day } 8 \text { and oxaliplatin } 150 \mathrm{mg} \\
\text { day } 2 \text { and bevacizumab } 400 \mathrm{mg} \text { day I, every } 2 \mathrm{I} \text { days }\end{array}$ & & & & \\
\hline \multirow[t]{3}{*}{ From September 2 to October 19, 2015} & Gemcitabine $1.8 \mathrm{~g}$ day $\mathrm{I} /$ day 8 and bevacizumab & 3 & 1 & & \\
\hline & $400 \mathrm{mg}$ day I, every $2 \mathrm{I}$ days & & & & \\
\hline & Gemcitabine $1.8 \mathrm{~g}$ day $\mathrm{I}$, every $2 \mathrm{I}$ days & & 1 & PD & - \\
\hline From November 9, 2015, to October 12, 2016 & $\begin{array}{l}\text { Paclitaxel } 210 \mathrm{mg} \text { day I and bevacizumab } 400 \mathrm{mg} \\
\text { day I, every } 2 \mathrm{I} \text { days }\end{array}$ & 4 & 15 & PR & 14 \\
\hline From November II to December 7, 2016 & $\begin{array}{l}\text { Paclitaxel } 180 \mathrm{mg} \text { day I and oxaliplatin I } 50 \mathrm{mg} \text { day I } \\
\text { and bevacizumab } 400 \mathrm{mg} \text { day I, every } 2 \text { I days }\end{array}$ & & 2 & PD & - \\
\hline From January 14 to February 14,2017 & $\begin{array}{l}\text { Gefitinib } 250 \mathrm{mg} / \text { day and bevacizumab } 400 \mathrm{mg} \text { day I, } \\
\text { every } 2 \mathrm{I} \text { days }\end{array}$ & 5 & I & PD & - \\
\hline From March 3, 2017 to until now & $\begin{array}{l}\text { Afatinib } 40 \mathrm{mg} / \text { day and bevacizumab } 400 \mathrm{mg} \text { day I, } \\
\text { every } 2 \mathrm{I} \text { days }\end{array}$ & 6 & 4 & PR & 6 \\
\hline
\end{tabular}

Abbreviations: PD, progressive disease; PFS, progression-free survival; PR, partial response; RECIST, response evaluation criteria in solid tumors.

EGFR mutants located in exon 20 (incidence 1\%-2\%). ${ }^{10,20}$ Common mutations including exon 19 deletions and L858R in exon 21 have shown sensitivity to EGFR-TKIs, no matter which generations they are.${ }^{6,7}$ However, the effects of uncommon EGFR mutations such as S768I mutation remain largely unknown. Although the analysis of LUX-Lung 2, LUXLung 3, and LUX-Lung $6^{11}$ proved that eight patients with S768I mutation all showed partial remission with afatinib, the limitation is obvious since the sample size was small and only one patient had single S768I mutation. In addition, Kuiper et $\mathrm{al}^{21}$ and Beau-Faller et $\mathrm{a}^{22}$ discovered that the disease control rate (DCR) was better with EGFR-TKIs for complex mutations than for a single mutation. Although some cases could be explained because they carried attractive mutations such as 19 deletions or L858R in exon 21 simultaneously, most conditions remain unclear.

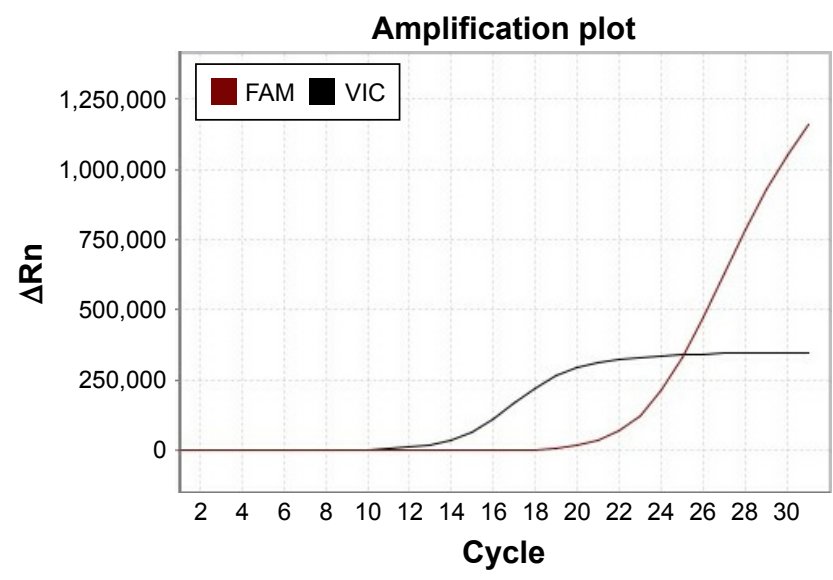

Figure 2 Circulating tumor DNA liquid biopsy shows 57689 mutation by the ARMS.
The female patient carried single S768I mutation according to two molecular pathologic tests. The effects of first- and second-generation EGFR-TKIs were completely different. To evaluate the effect of the single S768I mutation on the response to TKIs, we reviewed the previous cases and studies (Table 2). Table 2 shows that all the patients accepting afatinib showed partial remission or stable disease. The DCR is 100\%. By contrast, the DCR of patients who accepted the first-generation TKIs such as erlotinib, gefitinib, and icotinib was 46.2\%. Our case showed similar result. In addition to clinical researches, some experimental studies confirmed the value of different TKIs on S768I mutation. Tanizaki et $\mathrm{al}^{23}$ examined the sensitivity of $\mathrm{Ba} / \mathrm{F} 3$ cells expressing EGFR (L858R) or EGFR (S768I) to EGFR-TKIs by calculating the median inhibitory concentration $\left(\mathrm{IC}_{50}\right)$ values and a ratio relative to those for cells expressing EGFR (L858R). The result was inspiring because the $\mathrm{IC}_{50}$ values of afatinib were minimal. Regarding the $\mathrm{IC}_{50}$ ratios, the second-generation drugs' ratios were much smaller than those of the first- and the third-generation drugs. Kancha et $\mathrm{al}^{24}$ and Banno et $\mathrm{al}^{25}$ carried out similar experiments and drew similar conclusions. Therefore, S768I mutation is more sensitive to the second-generation TKI (afatinib) than the firstgeneration TKIs (erlotinib, gefitinib, and icotinib).

Up to now, 6-month PFS was achieved from afatinib combined with bevacizumab. The NEJ002 study ${ }^{26}$ found that the median survival time of patients treated with gefitinib, platinum, and pemetrexed or docetaxel was around 3 years. Previous studies proved the benefits of EGFR-TKIs combined with anti-vascular endothelial growth factor therapy, such as bevacizumab and apatinib. ${ }^{27-29}$ Furthermore, the 

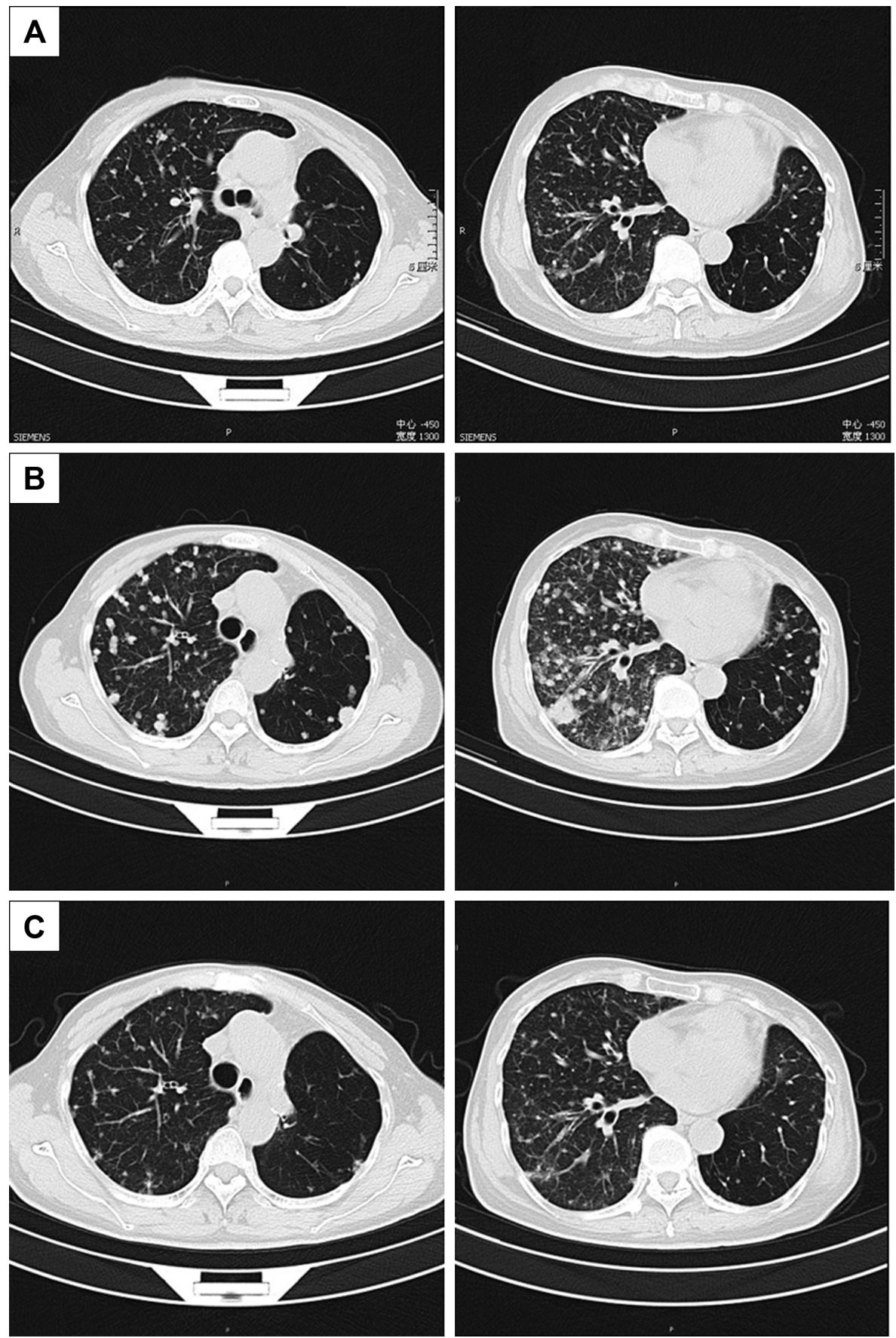

Figure 3 Thoracic computed tomography (CT) before taking gefitinib (A); after taking gefitinib, metastases increased widely in both lungs (B); after taking afatinib for one month, the metastases shrank obviously $(\mathbf{C})$.

European Society for Medical Oncology ${ }^{30}$ recommends bevacizumab combined with erlotinib as the first-line therapy for metastatic NSCLC. Comprehensive treatment could bring benefits to advanced NSCLC patients.

T790M mutation accounted for half of the known mechanisms of resistance. ${ }^{31}$ Patients with single S768I mutation also acquired secondary T790M mutation..$^{19,32}$ Meanwhile, another clinical case ${ }^{33}$ reported that patients with L858R mutation showed resistance after TKI therapy and secondary
S768I mutation occurred in repeated molecular pathology. May be the occurrence of secondary S768I mutation could be the potential resistance mechanism.

\section{Conclusion}

Our case indicates that the second-generation TKI (afatinib) could be better than the first-generation TKI (gefitinib). Afatinib may be an effective treatment for NSCLC patients with single S768I mutation. Comprehensive treatment could 
Table 2 Summary of reported clinical response to TKIs in patients harboring the single EGFR S768I mutation

\begin{tabular}{|c|c|c|c|c|c|c|c|c|c|c|c|c|}
\hline Author & Year & $\mathbf{n}$ & Nationality & Age & Sex & Smoking & Stage & EGFR-TKI & Prior therapy & Line & RECIST & PFS \\
\hline Masago et $\mathrm{al}^{34}$ & 2010 & I & Japanese & 81 & M & 37 pack-years & IV & Gefitinib & - & 2 & PR & 46I days \\
\hline Lund-Iversen et $\mathrm{al}^{35}$ & 2012 & I & Norwegian & 73 & $\mathrm{~F}$ & Former & IV & Erlotinib & Chemotherapy & 2 & PD & I month \\
\hline Weber et $\mathrm{al}^{36}$ & 2014 & I & Danish & - & & - & IV & Erlotinib & Chemotherapy & 2 & PD & I month \\
\hline Hellmann et al ${ }^{19}$ & 2014 & I & American & - & - & 5 pack-years & IV & Erlotinib & - & I & PR & 8 years \\
\hline \multirow[t]{2}{*}{ Pallan et $\mathrm{al}^{37}$} & 2014 & 2 & Afro-Caribbean & 56 & M & I pack-year & IV & Gefitinib & - & I & PD & 6 weeks \\
\hline & & & Caucasian & 65 & $\mathrm{~F}$ & 20 pack-years & IV & Erlotinib & Chemotherapy & 2 & PD & 2 months \\
\hline Chiu et $\mathrm{al}^{38}$ & 2015 & 6 & Taiwanese & - & - & - & - & $\begin{array}{l}\text { Gefitinib or } \\
\text { erlotinib }\end{array}$ & - & - & $\begin{array}{l}\text { 2PD, } \\
2 \mathrm{PR}, 2 \mathrm{SD}\end{array}$ & - \\
\hline Heigener et $\mathrm{al}^{39}$ & 2015 & I & German & - & - & - & - & Afatinib & - & - & SD & - \\
\hline Yang et $\mathrm{al}^{40}$ & 2015 & I & Chinese & 56 & $\mathrm{~F}$ & - & IV & Afatinib & - & I & PR & 5 months \\
\hline Yang et al"I & 2015 & I & - & - & - & - & - & Afatinib & - & - & PR & - \\
\hline Leventakos et $\mathrm{al}^{4 \mathrm{I}}$ & 2016 & I & - & - & - & - & IV & Gefitinib & - & - & PD & 3 months \\
\hline Klughammer et $\mathrm{al}^{42}$ & 2016 & I & - & - & - & - & - & Erlotinib & - & - & PR & - \\
\hline Cheng et $\mathrm{al}^{43}$ & 2016 & I & Chinese & 59 & $\mathrm{~F}$ & - & IV & IG-TKI & - & - & $P R$ & 8.6 months \\
\hline Kobayashi et a ${ }^{44}$ & 2016 & I & Japanese & 61 & $\mathrm{~F}$ & - & IV & Afatinib & - & 11 & PR & 12 months \\
\hline Zhang et al ${ }^{45}$ & 2017 & 1 & Chinese & 64 & M & - & - & Icotinib & - & 2 & SD & 31 months \\
\hline Zhu et al ${ }^{46}$ & 2017 & I & Chinese & 52 & $\mathrm{~F}$ & - & Illa & Gefitinib & - & I & SD & 8.8 months \\
\hline Russo et $\mathrm{a}^{32}$ & 2017 & 1 & Italian & 65 & M & - & IV & Afatinib & - & I & PR & 3 months \\
\hline
\end{tabular}

Abbreviations: IG, first-generation; EGFR, epidermal growth factor receptor; F, female; M, male; PD, progressive disease; PFS, progression-free survival; PR, partial response; RECIST, response evaluation criteria in solid tumors; SD, stable disease; TKI, tyrosine kinase inhibitor.

bring benefits to advanced NSCLC patients. However, further clinical data are required for patients with advanced NSCLC harboring a single S768I mutation in order to provide more powerful evidences.

\section{Acknowledgments}

This case report was supported by China-Japan Friendship Hospital. We would like to thank Resident Huang Chen (Pathology Department, China-Japan Friendship Hospital, Beijing, China) for pathologic reading. Our thanks also go to Professor Qing Wu (English Department, School of Humanities, Beijing University of Chinese Medicine, Beijing, China) and Liang Liang (a postgraduate studying Translation Theory and Practice at Renmin University of China) for improving language quality. We also express our gratitude to the patient and her husband. HD and YP are co-first authors.

\section{Author contributions}

$\mathrm{HD}, \mathrm{HC}, \mathrm{YP}$, and YQ were responsible for collection and assembly of the patient's data. HD, YP, QL, JZ, WS, CS, and CL performed data analysis and literature searching. All authors contributed toward data analysis, drafting and revising the paper and agree to be accountable for all aspects of the work.

\section{Disclosure}

The authors report no conflicts of interest in this work.

\section{References}

1. Torre LA, Bray F, Siegel RL, Ferlay J, Lortet-Tieulent J, Jemal A. Global cancer statistics, 2012. CA Cancer J Clin. 2015;65(2):87-108.
2. Chen W, Zheng R, Baade PD, et al. Cancer statistics in China, 2015. CA Cancer J Clin. 2016;66(2):115-132.

3. Zhou C, Wu YL, Chen G, et al. Erlotinib versus chemotherapy as first-line treatment for patients with advanced EGFR mutationpositive non-small-cell lung cancer (OPTIMAL, CTONG-0802): a multicentre, open-label, randomised, phase 3 study. Lancet Oncol. 2011;12(8):735-742.

4. Rosell R, Carcereny E, Gervais R, et al. Erlotinib versus standard chemotherapy as first-line treatment for European patients with advanced EGFR mutation-positive non-small-cell lung cancer (EURTAC): a multicentre, open-label, randomised phase 3 trial. Lancet Oncol. 2012;13(3):239-246.

5. Mitsudomi T, Morita S, Yatabe Y, et al; West Japan Oncology Group. Gefitinib versus cisplatin plus docetaxel in patients with non-smallcell lung cancer harbouring mutations of the epidermal growth factor receptor (WJTOG3405): an open label, randomised phase 3 trial. Lancet Oncol. 2010;11(2):121-128.

6. Lynch TJ, Bell DW, Sordella R, et al. Activating mutations in the epidermal growth factor receptor underlying responsiveness of non-small-cell lung cancer to gefitinib. $N$ Engl J Med. 2004;350(21):2129-2139.

7. Paez JG, Janne PA, Lee JC, et al. EGFR mutations in lung cancer: correlation with clinical response to gefitinib therapy. Science. 2004;304(5676):1497-1500.

8. Wu T, Hsiue EH, Lee JH, Lin CC, Yang JC. New data on clinical decisions in NSCLC patients with uncommon EGFR mutations. Expert Rev Respir Med. 2016;11(1):51-55.

9. Improta G, Pettinato A, Gieri S, et al. Epidermal growth factor receptor exon 20 p.S768I mutation in non-small cell lung carcinoma: a case report combined with a review of the literature and investigation of clinical significance. Oncol Lett. 2015;11(1):393-398.

10. Kobayashi Y, Mitsudomi T. Not all epidermal growth factor receptor mutations in lung cancer are created equal: perspectives for individualized treatment strategy. Cancer Sci. 2016;107(9):1179-1186.

11. Yang JC, Sequist LV, Geater SL, et al. Clinical activity of afatinib in patients with advanced non-small-cell lung cancer harbouring uncommon EGFR mutations: a combined post-hoc analysis of LUX-Lung 2, LUX-Lung 3, and LUX-Lung 6. Lancet Oncol. 2015;16(7):830-838.

12. Ettinger DS, Wood DE, Akerley W, et al. NCCN guidelines insights: non-small cell lung cancer, version 4.2016. J Natl Compr Canc Netw. 2016;14(3):255-264. 
13. Zhou $\mathrm{C}, \mathrm{Wu} \mathrm{Y}$, Chen G, et al. BEYOND: a randomized, double-blind, placebo-controlled, multicenter, phase III study of first-line carboplatin/paclitaxel plus bevacizumab or placebo in Chinese patients with advanced or recurrent nonsquamous non-small-cell lung cancer. $J$ Clin Oncol. 2015;33(19):2197-2204.

14. Reck M, von Pawel J, Zatloukal P, et al. Overall survival with cisplatingemcitabine and bevacizumab or placebo as first-line therapy for nonsquamous non-small-cell lung cancer: results from a randomised phase III trial (AVAiL). Ann Oncol. 2010;21(9):1804-1809.

15. Reck M, von Pawel J, Zatloukal P, et al. Phase III trial of cisplatin plus gemcitabine with either placebo or bevacizumab as first-line therapy for nonsquamous non-small-cell lung cancer: AVAil. J Clin Oncol. 2009;27(8):1227-1234.

16. Sandler A, Yi J, Dahlberg S, et al. Treatment outcomes by tumor histology in Eastern Cooperative Group Study E4599 of bevacizumab with paclitaxel/carboplatin for advanced non-small cell lung cancer. J Thorac Oncol. 2010;5(9):1416-1423.

17. Reck M, Hagiwara K, Han B, et al. ctDNA determination of EGFR mutation status in European and Japanese patients with advanced NSCLC: the ASSESS Study. J Thorac Oncol. 2016;11(10):1682-1689.

18. Schwaederle MC, Patel SP, Husain H, et al. Utility of genomic assessment of blood-derived circulating tumor DNA (ctDNA) in patients with advanced lung adenocarcinoma. Clin Cancer Res. 2017;23(17): 5101-5111.

19. Hellmann MD, Reva B, Yu H, et al. Clinical and in vivo evidence that EGFR S768I mutant lung adenocarcinomas are sensitive to erlotinib. J Thorac Oncol. 2014;9(10):e73-e74.

20. Arcila ME, Nafa K, Chaft JE, et al. EGFR exon 20 insertion mutations in lung adenocarcinomas: prevalence, molecular heterogeneity, and clinicopathologic characteristics. Mol Cancer Ther. 2013;12(2): 220-229.

21. Kuiper JL, Hashemi SMS, Thunnissen E, et al. Non-classic EGFR mutations in a cohort of Dutch EGFR-mutated NSCLC patients and outcomes following EGFR-TKI treatment. Br J Cancer. 2016;115(12): 1504-1512.

22. Beau-Faller M, Prim N, Ruppert AM, et al. Rare EGFR exon 18 and exon 20 mutations in non-small-cell lung cancer on 10117 patients: a multicentre observational study by the French ERMETIC-IFCT network. Ann Oncol. 2014;25(1):126-131.

23. Tanizaki J, Banno E, Togashi Y, et al. Case report: durable response to afatinib in a patient with lung cancer harboring two uncommon mutations of EGFR and a KRAS mutation. Lung Cancer. 2016;101: $11-15$.

24. Kancha RK, von Bubnoff N, Peschel C, Duyster J. Functional analysis of epidermal growth factor receptor (EGFR) mutations and potential implications for EGFR targeted therapy. Clin Cancer Res. 2009;15(2): 460-467.

25. Banno E, Togashi Y, Nakamura Y, et al. Sensitivities to various epidermal growth factor receptor-tyrosine kinase inhibitors of uncommon epidermal growth factor receptor mutations L861Q and S768I: what is the optimal epidermal growth factor receptor-tyrosine kinase inhibitor? Cancer Sci. 2016;107(8):1134-1140.

26. Inoue A, Kobayashi K, Maemondo M, et al; North-East Japan Study Group. Updated overall survival results from a randomized phase III trial comparing gefitinib with carboplatin-paclitaxel for chemo-naive nonsmall cell lung cancer with sensitive EGFR gene mutations (NEJ002). Ann Oncol. 2013;24(1):54-59.

27. Seto T, Kato T, Nishio M, et al. Erlotinib alone or with bevacizumab as first-line therapy in patients with advanced non-squamous nonsmall-cell lung cancer harbouring EGFR mutations (JO25567): an open-label, randomised, multicentre, phase 2 study. Lancet Oncol. 2014; 15(11):1236-1244.

28. Otsuka K, Hata A, et al. EGFR-TKI rechallenge with bevacizumab in EGFR-mutant non-small cell lung cancer. Cancer Chemother Pharmacol. 2015;76(4):835-841.
29. Peng Y, Cui H, Liu Z, et al. Apatinib to combat EGFR-TKI resistance in an advanced non-small cell lung cancer patient with unknown EGFR status: a case report. Onco Targets Ther. 2017;10:2289-2295.

30. Novello S, Barlesi F, Califano R, et al. Metastatic non-small-cell lung cancer: ESMO clinical practice guidelines for diagnosis, treatment and follow-up. Ann Oncol. 2016;27(Suppl 5):v1-v27.

31. Sequist LV, Waltman BA, Dias-Santagata D, et al. Genotypic and histological evolution of lung cancers acquiring resistance to EGFR inhibitors. Sci Transl Med. 2011;3(75):75ra26.

32. Russo A, Franchina T, Ricciardi GRR, Adamo V. Rapid acquisition of T790M mutation after treatment with afatinib in an NSCLC patient harboring EGFR Exon 20 S768I mutation. J Thorac Oncol. 2017;12(1): e6-e8.

33. Longo L, Mengoli MC, Bertolini F, Bettelli S, Manfredini S, Rossi G. Synchronous occurrence of squamous-cell carcinoma "transformation" and EGFR exon 20 S768I mutation as a novel mechanism of resistance in EGFR-mutated lung adenocarcinoma. Lung Cancer. 2017;103: 24-26.

34. Masago K, Fujita S, Irisa K, et al. Good clinical response to gefitinib in a non-small cell lung cancer patient harboring a rare somatic epidermal growth factor gene point mutation; Codon 768 AGC $>$ ATC in Exon 20 (S768I). Jpn J Clin Oncol. 2010;40(11):1105-1109.

35. Lund-Iversen M, Kleinberg L, Fjellbirkeland L, Helland A, Brustugun OT. Clinicopathological characteristics of 11 NSCLC patients with EGFRexon 20 mutations. $J$ Thorac Oncol. 2012;7(9):1471-1473.

36. Weber B, Hager H, Sorensen BS, et al. EGFR mutation frequency and effectiveness of erlotinib: a prospective observational study in Danish patients with non-small cell lung cancer. Lung Cancer. 2014;83(2): 224-230.

37. Pallan L, Taniere P, Koh P. Rare EGFR exon 20 S768I mutation predicts resistance to targeted therapy: a report of two cases. J Thorac Oncol. 2014;9(10): 75

38. Chiu CH, Yang CT, Shih JY, et al. Epidermal growth factor receptor tyrosine kinase inhibitor treatment response in advanced lung adenocarcinomas with G719X/L861Q/S768I mutations. J Thorac Oncol. 2015;10(5):793-799.

39. Heigener DF, Schumann C, Sebastian M, et al; Afatinib Compassionate Use Consortium (ACUC). Afatinib in non-small cell lung cancer harboring uncommon EGFR mutations pretreated with reversible EGFR inhibitors. Oncologist. 2015;20(10):1167-1174.

40. Yang X, Chen H, Zhang H, et al. [Effectiveness of tyrosine kinase inhibitors on uncommon epidermal growth factor receptor mutations in nonsmall cell lung cancer]. Zhongguo Fei Ai Za Zhi. 2015;18(8):493-499. Chinese.

41. Leventakos K, Kipp BR, Rumilla KM, Winters JL, Yi ES, Mansfield AS. S768I mutation in EGFR in patients with lung cancer. $J$ Thorac Oncol. 2016;11(10):1798-1801.

42. Klughammer B, Brugger W, Cappuzzo F, et al. Examining treatment outcomes with erlotinib in patients with advanced non-small cell lung cancer whose tumors harbor uncommon EGFR mutations. $J$ Thorac Oncol. 2016;11(4):545-555.

43. Cheng G, Song Z, Chen D. Clinical efficacy of first-generation EGFRTKIs in patients with advanced non-small-cell lung cancer harboring EGFR exon 20 mutations. Onco Targets Ther. 2016;9:4181-4186.

44. Kobayashi $\mathrm{H}$, Wakuda K, Takahashi T. Effectiveness of afatinib in lung cancer with paralytic ileus due to peritoneal carcinomatosis. Respirol Case Rep. 2016;4(6):e0197.

45. Zhang Y, Wang Z, Hao X, et al. Clinical characteristics and response to tyrosine kinase inhibitors of patients with non-small cell lung cancer harboring uncommon epidermal growth factor receptor mutations. Chin J Cancer Res. 2017;29(1):18-24.

46. Zhu X, Bai Q, Lu Y, et al. Response to tyrosine kinase inhibitors in lung adenocarcinoma with the rare epidermal growth factor receptor mutation S768I: a retrospective analysis and literature review. Target Oncol. 2017;12(1):81-88. 
OncoTargets and Therapy

\section{Publish your work in this journal}

OncoTargets and Therapy is an international, peer-reviewed, open access journal focusing on the pathological basis of all cancers, potential targets for therapy and treatment protocols employed to improve the management of cancer patients. The journal also focuses on the impact of management programs and new therapeutic agents and protocols on

patient perspectives such as quality of life, adherence and satisfaction. The manuscript management system is completely online and includes a very quick and fair peer-review system, which is all easy to use. Visit http://www.dovepress.com/testimonials.php to read real quotes from published authors.

Submit your manuscript here: http://www.dovepress.com/oncotargets-and-therapy-journal 